\title{
A Response to "Educational Utility of Social Media for Laparoscopic Surgery in India: A Cross-Sectional Survey of Popular Indian Communities on Facebook" [Letter]
}

\section{Denise Jia Yun Tan}

University of Nottingham, Nottingham, NG7 2UH, UK
Correspondence: Denise Jia Yun Tan University of Nottingham, Derby Road, Lenton, Nottingham, NG7 2UH, UK Tel +447845075I59

Email dtjy27@doctors.org.uk

\section{Dear editor}

I read, with great interest, the recent article by Rajan et $\mathrm{al}^{1}$ regarding the focus on innovative approaches to postgraduate training in laparoscopic surgery, which is a pertinent issue against the backdrop of the current COVID-19 pandemic and its social distancing requirements. The authors offered a unique viewpoint by investigating how social media can be used in developing countries to offset training challenges during the pandemic. As a junior doctor who utilises social media for surgical exam revisions, I am familiar with the use of social media in accessing a variety of medical education resources and aware of the potential application in learning laparoscopically through virtual reality training and simulations. ${ }^{2}$

The paper correctly identifies alternative training techniques and how they can be capitalised upon to address the inability to use conventional apprenticeship methods for postgraduate training. The study is, however, limited due to its methodology. The crosssectional design of the study may be concomitant with some biases since its sample size was undefined and there is also the potential for selection bias. Since the data was collected during the pandemic, the study does not account for the fact that more learners have transitioned to learning online due to the pandemic. ${ }^{3}$ The social distancing protocols associated with the pandemic have compelled universities to adopt new learning techniques predominantly based on virtual platforms. There is an argument to be made, which in the current climate, it could also be the case that the research sample is predisposed to, or has become familiar with online modes of learning. This may, in turn, imply that social media is not necessarily a better learning option for students, but one that they have become increasingly familiar with due to the pandemic.

Furthermore, the nature of the Facebook educational posts and reactions may have been influenced by confounding factors such as the mental health of group participants. The COVID-19 pandemic has been shown to have a psychological impact on individuals in the form of anxiety, depression and stress. ${ }^{4}$ Anxiety has also been linked with conforming behaviours, whereby people who are anxious tend to keep their opinions in agreeance with that of the majority. ${ }^{4}$ There is the possibility that the research participants may be conforming with what they believe to be the dominant perception in the research; however, this has not been accounted 
for by the researchers. Mental health as a confounding factor must be incorporated into future studies that are pandemic-related, in order to mitigate against any biases.

To conclude, the potential benefits of utilising social media platform can be complementary to traditional teaching methods. However, future studies are needed to investigate how familiarity with online learning linked to the pandemic may introduce biases in the responses of respondents.

\section{Disclosure}

The author reports no conflicts of interest in this communication.

\section{References}

1. Rajan D, Pillai VG, Varghese P. Educational utility of social media for laparoscopic surgery in India: a cross-sectional survey of popular Indian communities on Facebook. Adv Med Educ Pract. 2021;12: 491-498. doi:10.2147/AMEP.S306680

2. Larsen CR, Soerensen JL, Grantcharov TP, et al. Effect of virtual reality training on laparoscopic surgery: randomised controlled trial. BMJ. 2009;15:338. doi:10.1136/bmj.b1802

3. Sujarwo S, Sukmawati S, Akhiruddin A, Ridwan R, Siradjuddin SS. An analysis of university students' perspective on online learning in the midst of covid-19 pandemic. Journal Pendidikan Dan Pengajaran. 2020;53(2):125-137. doi:10.23887/jpp.v53i2.24964

4. Feng C, Cao J, Li Y, Wu H, Mobbs D. The pursuit of social acceptance: aberrant conformity in social anxiety disorder. Soc Cogn Affect Neurosci. 2018;13(8):809-817. doi:10.1093/scan/nsy052

Dove Medical Press encourages responsible, free and frank academic debate. The content of the Advances in Medical Education and Practice 'letters to the editor' section does not necessarily represent the views of Dove Medical Press, its officers, agents, employees, related entities or the Advances in Medical Education and Practice editors. While all reasonable steps have been taken to confirm the content of each letter, Dove Medical Press accepts no liability in respect of the content of any letter, nor is it responsible for the content and accuracy of any letter to the editor.

\section{Publish your work in this journal}

Advances in Medical Education and Practice is an international, peerreviewed, open access journal that aims to present and publish research on Medical Education covering medical, dental, nursing and allied health care professional education. The journal covers undergraduate education, postgraduate training and continuing medical education including emerging trends and innovative models linking education, research, and health care services. The manuscript management system is completely online and includes a very quick and fair peer-review system. Visit http://www.dovepress.com/testimonials.php to read real quotes from published authors. 